\title{
MULTIDISCIPLINARY APPROACH TO THE ANALYSIS OF THE PROCESS OF PERCEIVING WARNING SIGNALS
}

\author{
Bogdan ĆWIK, Ph.D. Eng. \\ Institute of Security and Defence Systems \\ Military University of Technology, Warsaw, Poland \\ bogdan.cwik@wat.edu.pl
}

\begin{abstract}
The article presents the results of research and literature studies in terms of the perception of threats. The author presents the main factors affecting the quality and efficiency of the perception of threats. The paper firstly looks at an integrated model of the perception of the warning signal and, secondly, the complexity and multidiscipline of the approach required by this model, arguing and advocating broadening the field of interest in security sciences to other fields and disciplines.
\end{abstract}

Key words: perception of threats, threats, warning, warning, early warning system

\section{Introduction}

The theory and practice of security are inseparable from the perception of threats and the basic way of counteracting any threats is monitoring them, which Romuald Kalinowski describes as follows: It seems that monitoring threats has as long a history as human history. In all eras, people tried to warn each other against 
danger in different ways. It didn't always have the desired result, but it was done ${ }^{1}$. Key elements of any monitoring system are the hazard identification systems and related warning subsystems. This leads to a deeper reflection on the perception of threats. At first glance, it seems that the problem of perceiving threats has already been thoroughly investigated and developed in psychology and biological sciences, but it seems useful to propose an approach to this problem from the perspective of science on safety.

The main research topicof this paper is the unsatisfactory effectiveness of warning systems operating in complex, dispersed, unstable and dynamic contemporary reality, which significantly affects the real and perceived level of security and, consequently, results in the inadequate attitudes and behaviour of people in dangerous situations.

When preparing this paper, the author set two goals. The first is to identify the underlying factors affecting the disruptions and distortions of the perception of warning signals, and the other is to demonstrate the need for a multidisciplinary approach to the theoretical and research problems solved in science on security.

The solution of this research and the achievement of the objectives will be implemented by means of literature studies, observation and case analysis, mental simulation, as well as the author's own research on behaviour and attitudes in the face of threats, of socio-economic systems such as employees of enterprises and investors in the financial markets.

\section{Executive aspects of basic cognitive processes}

Identification and recognition of threats are mainly related to the realisation of cognitive processes and principally take place in the psychological internal structures of the individual that monitors threats. During the study of this problem, it turned out to be beneficial to refer to the selected areas of the cognitive psychology, which is a separate field of psychology, based on many other sciences,

1 R. Kalinowski, Monitorowanie zagrożeń, Wydawnictwo Akademii Podlaskiej w Siedlcach, Siedlce 2003, p. 6. 
including primarily neuroscience, linguistics, anthropology and philosophy. In many areas, this field also coincides with the sciences on cognition and social communication. Cognitive psychology is also associated with research areas that exist within general psychology, such as biopsychology, developmental psychology, social psychology, and clinical psychology. The definition of cognitive psychology was adopted by Robert J. Sternberg, who defined cognitive psychology as follows: Cognitive psychology deals with how people receive information, learn, remember, thin $k^{2}$. More complex, methodological definitions that place cognitive psychology in the field of psychological sciences are presented in numerous works in this area, e.g., of: Jerzy Bobryk, Alina Kolańczyk, Maria A. Zając, Michael Tomasello, Edward Nęcka, Tadeusz Maruszewski ${ }^{3}$ and others.

Simultaneously, it appeared to be obvious and necessary to take into account, when working on the perception of warning signals, that the process of perceiving hazard signals takes place in a specific environment. It is based on issues derived from historical development, technological and social structures of storage and transfer of signs that make up the media, where creators of modern media theory were analysed, including: Herbert Marshall Mcluhan, Derrick de Kerckhove, Paul Virilio, Harold A. Innis, Friedrich A. Kittler, Erving Goffman, John Urry ${ }^{4}$. Other authors in this area are: Lev Manovicz, Paul Levinson, Dieter Mersch, Tomasz Goban-Klas,

2 R.J. Sternberg, Psychologia poznawcza, WSiP, Warsaw 2001.

3 J. Bobryk, Akty świadomości i procesy poznawcze, Leopoldinum, Wrocław 1996; A. Kolańczyk, Czuję, myślę, jestem: świadomość i procesy psychiczne w ujęciu poznawczym, Gdańskie Wydawnictwo Psychologiczne, Gdańsk 1999; A.M. Zając, Fenomenologiczne watki w psychologii poznania: badania Danuty Gierulanki nad przyswajaniem pojęć i rozumieniem tekstu, Wydawnictwo Uniwerytetu Śląskiego, Katowice 2012; M. Tomasello, Kulturalne źródta ludzkiego poznawania, Państwowy Instytut Wydawniczy, Warsaw 2002; E. Nęcka, J. Orzechowski, B. Szymura, Psychologia poznawcza, PWN, Warsaw 2007; T. Maruszewski, Psychologia poznania. Umyst i świat, Gdańskie Wydaw. Psychologiczne GWP, Gdańsk 2011.

4 H.M. Mcluhan, Zrozumieć media: przedtużenia człowieka, Wydawnictwa NaukowoTechniczne, Warsaw 2004; D. deKerckhove, Powłoka kultury: odkrywanienowejelektronicznej rzeczywistości, Mikom, Warsaw 2001; P. Virilio, Prędkość i polityka, Wydawnictwo Sic!, Warsaw 2008; H.A. Innis, Empire and Communications, Dundurn Press, Toronto 2001; F.A. Kittler, Austreibung des Geistes aus den Geisteswissenschaften: Programme den Poststrukturalismus, F. Schöningh, Paderborn 1980; E. Goffman, Człowiek w teatrze życia codziennego, Wydawnictwo Aletheia, Warsaw 2008; J. Urry, Socjologia mobilności, PWN, Warsaw 2009. 
Krzysztof Loska, Emory A. Griffin, Aleksander Bard and Jan Soderqvist ${ }^{5}$ and others. Contemporary media has created an environment for collecting, transferring and transmitting information, including warning signals, which is not just the internet, radio and television, but also mobile networks, library networks, television networks and radio networks - media is everywhere. Tomasz Goban-Klas wrote this about the media: The technical ability to send signs and symbols immediately across the globe and thereby deliver the same content and emotion to the millions or billions of people has become common and is used day-to-day ${ }^{6}$. The media has become an evolving system that has constantly evolved and shaped the form and structure of modern social systems: economic, security, defence, culture, science, law, etc.

The author conducted his own experimental and theoretical studies from which we can distinguish the following groups of factors that have a decisive influence on the quality and effectiveness of hazard identification:

- signal visibility,

- cognitive conditions,

- individual differences between perceivers,

- the level of perceiver emotions,

- time or space distance to limit states in the outer or inner environment.

The first of these factors can be related to the sign and we can discuss the visibility of the perceived sign. But, the term "sign" is to be considered from the perspective of a separate research area, which is covered by the general theory of signs called semiology. In specialist publications, the term "semiotics" can be found, which was introduced in John Locke's "Essay concerning human understanding" and developed by Charles S. Peirce, where the process of interpretation of signs was

5 L. Manovich, Język nowych mediów, Wydawnictwa Akademickie i Profesjonalne 2006; P. Levinson, Miękkie ostrze, czyli historia i przyszłość rewolucji informacyjnej, Warszawskie Wydawnictwo Literackie Muza S.A., Warsaw 2006; D. Mersch, Teorie mediów, Wydawnictwo Sic!, Warsaw 2010; T. Goban-Klas, Media i komunikowanie masowe. Teorie i analizy prasy, radia, telewizji i internetu, PWN, Kraków 1999; T. Goban-Klas, Cywilizacja medialna. Geneza, ewolucja, eksplozja, Wydawnictwa Szkolne i Pedagogiczne, Warsaw 2005; K. Loska, Dziedzictwo McLuhana - między nowoczesnościa a ponowoczesnościa, Rabid, Kraków 2001; E.A. Griffin, Podstawy komunikacji społecznej, Gdańskie Wydawnictwo Psychologiczne, Gdańsk 2003; A. Bard, J. Soderqvist, Netokracja: nowa elita władzy i życie po kapitalizmie, Wydawnictwa Akademickie i Profesjonalne, Warsaw 2006.

6 T. Goban-Klas, Media i komunikowanie..., op. cit., p. 13.

7 J. Locke, Rozważania dotyczace rozumu ludzkiego, PWN, Warsaw 1955. 
called "semiosis". Taking this approach, the sign can be considered according to Charles S. Peirce's Theory of Signs ${ }^{8}$ and its development presented by Elina Hiltunen ${ }^{9}$ in the form of a three-dimensional model of visibility of the future sign (Fig. 1). The dashed line shown in Fig. 1 can be interpreted as the trajectory of the visibility of a sign containing a warning signal.

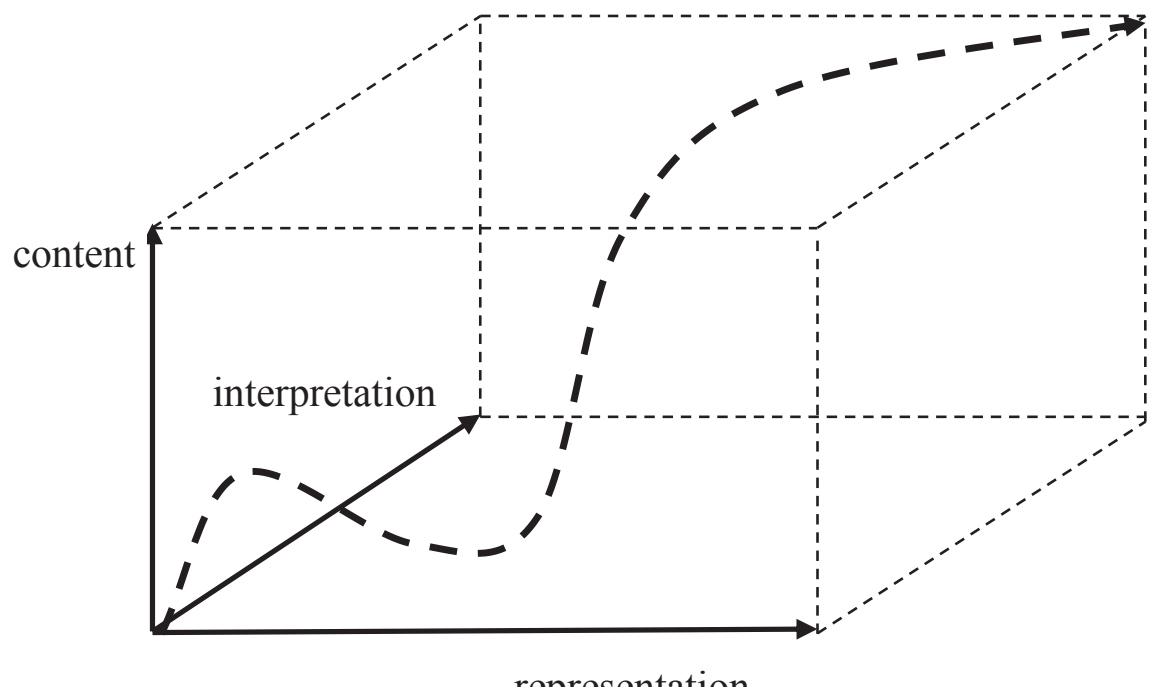

representation

Source: Based on: Hiltunen (2008).

Fig. 1. Three-dimensional model of a sign containing the warning signal

The model illustrated in Figure 1 shows the triadic concept of a warning sign, in which we can distinguish three components: interpretation, representation and content of the sign, which means the size of a negative impact causing a decrease in the security level of the analysed system. A specific level of visibility can be assigned to each of these components. In the process of perception, the observer or the analyst directly reads the representation of the signs, where the dashes read on the thermometer are a representation and the correlated content (reaction) is the temperature. However, it still requires interpretation, since, e.g. a read value of 40 Celsius degrees may present a significant risk if itrelates to human

8 P. Janik, Koncepcja przekonania w ujęciu semiotyczno-pragmatycznym: Charles S. Peirce, Wydawnictwo WAM, Kraków 2011, p. 81-115.

9 E. Hiltunen, The Future Sign and Its Three Dimension, „Futures”, vol. 40, No 3, 2008. 
body temperature or ambient temperature, but in a cooling system of an internal combustion engine or in a home heating system, it proves the proper operation of the devices. At the same time, each of the components of such a sign can be expressed on a specific measuring scale, in which we can point to the initial value, for example zero or insignificant value, the intermediate values and the final value (very significant). The more detailed arguments are contained in Bogdan Ćwik's papers on signal perception and effectiveness of hazard identification: "Postrzeganie sygnałów..." ${ }^{10}$ and "Skuteczność rozpoznania sygnałów..."11.

The next factor influencing the quality and effectiveness of cognitive processes, requiring the incorporation of theories, methodologies and practices from other scientific disciplines, are the cognitive conditions in which the process of perceiving warning signals takes place. From this point of view, these conditions can be divided into:

- Conditions of certainty - including known phenomena, events and situations, previously identified as to their nature and possible effects, whereas standard precautionary procedures are also known and operational.

- Conditions of probability - including random phenomena, events and situations, in which they were examined and the parameters determining the occurrence of these phenomena, events or situations were identified. The probability of their occurrence is determined by the frequency of their occurrence, expressed by means of probability calculus, statistics, stochastic process theory, risk analysis and others. Standard precautionary procedures for these conditions are also known and operational.

- Conditions of uncertainty - include the division into: uncertainty conditions (uncertainty type I) and conditions of ignorance (uncertainty type II). According to Katarzyna Jędralska ${ }^{12}$, uncertainty type I occurs when consequences or effects of events are known and only their probability is unknown. They are most often evaluated on the basis of subjective probability. While uncertainty

10 B. Ćwik, Postrzeganie sygnałów ostrzegajacych organizacje w sytuacjach niedeterministycznych, WAT, Warsaw 2017.

11 B. Ćwik, Skuteczność rozpoznania sygnałów o zagrożeniach - aspekty teorii znaków [in:] J. Żylińska, I. Przychocka, M. Filipowska-Tuthill, Wspótczesne wyzwania nauk społecznych i ekonomicznych, Uczelnia Techniczno- Handlowa im. Heleny Chodkowskiej w Warszawie, Warsaw 2016, pp. 249-270.

12 K. Jędralska, Zarzadzanie niepewnościa, Uniwersytet Ekonomiczny w Katowicach, Katowice 2010. 
type II occurs when the consequences or effects of certain events are also unknown.

Another factor affecting the quality and effectiveness of the executive process when perceiving threat signals, also requiring references to other scientific disciplines, are individual differences, including: intelligence, personality, temperament, ability and cognitive style ${ }^{13}$. As a result of individual differences, people differ in terms of individual physical and mental characteristics. For instance, it is apparent in all examples that the stronger the stimulus, the shorter the response time, but people differ in terms of the response time to the individual stimuli. Another example may be the perception of a follow-up image that is recorded by everyone in situations when we are looking at something for a long time, but it persists for different times in different people.

The first of the indicated individual differences is personality, which is understood as the sum of ways of reacting to other people (and objects) and the ways they interact with each other, which are characteristic for the individual. Personality includes the permanent, intrinsic qualities of a man, which direct his thoughts and actions in various situations. It results later in the effectiveness of the processes of perception. Temperament is another individual difference, which, according to Jan Strelau ${ }^{14}$, is the regulating mechanism of human activity, that is, influences the course of activities in the energy dimension (size, intensity, energy intensity) and in the time dimension (time behaviour characteristics, i.e. speed, mobility, durability). The next individual difference is the capacity that determines the effectiveness of learning and task performance. Intelligence, on the other hand, is of a quality nature and can be understood as a set of mental abilities that enable the individual to use his or her acquired knowledge effectively and to behave in an effective way in response to new tasks and situations. Among other things, intelligence is the overall ability to perceive relationships and to draw conclusions. Intelligence is also the ability to look into complex relationships between objects. The last identified individual difference is the cognitive style that determines the preferred cognitive function. Cognitive styles are mainly revealed in free situations

13 J. Strelau, Różnice indywidualne: historia, determinanty, zastosowania, Wydawnictwo Naukowe Scholar: Szkoła Wyższa Psychologii Społecznej, Warsaw 1974, 2015.

14 J. Strelau, Psychologia różnic indywidualnych, Wydawnictwo Naukowe" Scholar", Warsaw 2006. 
undefined in terms of cognition. These styles affect human choices and situations, as well as ways of perception. Cognitive style involves the method of learning, perceiving, thinking, problem solving and information processing. There are several cognitive styles. One of them may be a reflective person who thinks for a long time, makes few mistakes and is opposed to an impulsive person.

The next factor is the level of emotions of the perceiver, understood as a complex set of physical and mental changes, including physiological, emotional stimulation, cognitive processes and behavioural responses, performed in response to a situation that is perceived as important. From the point of view of the principal problem of this study, that is the perception of danger signals, among the types of emotions mentioned in the literature, those that are the most visible in the perception of threats will be important. These emotions are primarily fear and anxiety, which are processed by completely separate areas of the brain and which, in the science of safety, should be distinguished, whereas fear is associated with rationality, it means conscious processing of information about a given threat. In an atmosphere of fear, information is processed using the cerebral cortex. As a result, in conditions of fear, standard processes of thinking are carried out including processes of reasoning, as well as processes of imagination. But anxiety is associated with the automatic realisation of scenarios encoded in the limbic system of the brain, where information processing goes beyond the cerebral cortex, triggering biological systems of rapid response created during evolutionary development.

The key factor causing "surprises" in the perception of threats is the state of tensions and stresses in the environment of the observed system. Identification during perception and taking into account the limits of tension and stress, along with the limits of hazard effects, should allow for effective detection of hazards. The occurrences that usually take place within those limits are described as "small causes causing significant effects". The system is in the limit state if in the given conditions of tension and stress in the system surrounding it, at least one of the effects (that is the casual threat) has reached a limit beyond which the system will suffer permanent and negative quality changes, including serious impairment of the functions performed by this system or their fall.

Theoretical bases of system behaviour in limit states are covered by limit states theory. In general, the theory of limit states is multidisciplinary and includes: 
- limit states in diagnostics and building construction ${ }^{15}$, in diagnostics and construction of machines ${ }^{16}$;

- critical points of phase changes, concentration limits of mixtures (gases, liquids, solids $)^{17}$;

- limit states of ground and soil ${ }^{18}$;

- experiences and limit situations in psychology ${ }^{19}$, ethics ${ }^{20}$ and philosophy ${ }^{21}$;

- limit states in medical diagnostics ${ }^{22}$;

- limit sets and limits of a function, in mathematical analysis, in mathematical economics ${ }^{23}$;

- limit states and situations in economics ${ }^{24}$;

- limit states and situations in internal and international security systems;

15 L. Dietrich, Zastosowanie teorii stanów granicznych do wyznaczania obciażeń maszyn do robót ziemnych, Instytut Podstawowych Problemów Techniki Polskiej Akademii Nauk, Warsaw 1975.

16 A.Machowski(ed.),Zagadnieniastanówgranicznych konstrukcjistalowych, Konferencja naukowa 22-23 kwietnia 2004 r. Kraków, Wydawnictwo Politechniki Krakowskiej, Kraków 2004.

17 W. Cybulski, Graniczne stężenie wybuchowe pyłu węglowego jako funkcja stopnia jego rozdrobnienia, Główny Instytut Górnictwa, Katowice 1971; K. Kozakiewicz, Określenie granicznych składów gazów zaazotowanych, Centralne Laboratorium Gazownictwa, Warsaw 1967.

18 W. Szczepiński, Stany graniczne i kinematyka ośrodków sypkich, PWN, Warsaw 1974; R. Izbicki, Z. Mróz, Metody nośności granicznej w mechanice gruntów i skat, Polska Akademia Nauk, Instytut Państwowych Problemów Techniki, Warsaw-Poznań 1975; E. Dembicki, Stany graniczne gruntów, teoria $i$ zastosowanie, Zakład Narodowy im. Ossolińskich, Wrocław 1970.

19 M. Żelazny, Filozofia $i$ psychologia egzystencjalna, Wydawnictwo Naukowe Uniwersytetu Mikołaja Kopernika, Torun 2011.

20 D. Probucka, Etyka wobec sytuacji granicznych, Oficyna Wydawnicza „Impuls”, Kraków 2007.

21 R. Rudziński, Sytuacje graniczne w ujęciu Karla Jaspersa, Wiedza Powszechna, Warsaw 1978.

22 J. Wallach, Interpretacja badań laboratoryjnych, MediPage, Warsaw 2011.

23 Z. Przybycień et al., Zbiory graniczne i atraktory w modelach ekonomii matematycznej, Wydawnictwo Akademii Ekonomicznej im. Karola Adamieckiego, Katowice 2006.

24 W. Nawrot, Globalny kryzys finansowy XXI wieku. Przyczyny, przebieg, skutki, prognozy, CeDeWu, Warsaw 2009; W. Morawski, Kronika kryzysów gospodarczych, Wydawnictwo TRIO, Warsaw 2003; K. Marczak, K. Piech, Cykle koniunkturalne: ujęcie historyczne i przeglad głównych teorii [in:] Koniunktura gospodarcza: od bańki internetowej do kryzysu subprime, Wydawnictwo C.H. Beck, Warsaw 2009; J.M. Albala-Bertrand, M. Park, Disasters and the networked economy, Routledge, Abingdon, New York 2013. 
- limit states of biological ${ }^{25}$, political ${ }^{26}$, scientific $^{27}$; cultural and other breakthroughs ${ }^{28}$.

One feature of limit states is that further quantitative replacement of the amount of a given effect results in the activation of qualitative change. The intensity and scope of these changes depend on the tensions and stresses in the external and internal environment of the system. In the conditions of strong tensions and stresses in the external and internal environment, the probability of activating the mechanism of change, defined in the literature as "small causes cause great effects", increases. The problem was first formulated by Henry Poincare stating that: events, seemingly accidental, may be the result of causes that are difficult to grasp. [...] small causes may cause great effects ${ }^{29}$.

\section{Model of integrated warning signal perception}

The basis of this model are the cognitive processes of the observer watching the threat, including:

a) processes of attention, where attention consists of the processes that direct the awareness to an object, phenomenon or impact (effects) of the external and internal world;

b) processes of registration (reading) - processes in which the learner recognises, organises and gives meaning to the sensations received from external stimuli;

c) memory processes - processes of registering (reporting) and recalling sensory impressions, associations, information;

25 M. Graniczny, Katastrofy przyrodnicze, PWN, Warsaw 2007; E. Szathmary, Tajemnice przełomów w ewolucji: od narodzin życia do powstania mowy ludzkiej, PWN, Warsaw 2000.

26 J. Chodak, Teorie rewolucji w naukach społecznych, Wydawnictwo Uniwersytetu Marii Curie-Skłodowskiej, Lublin 2012.

27 T. Kuhn, Przewrót kopernikański: astronomia planetarna w dziejach myśli Zachodu, Prószyński i S-ka, Warsaw 2006; T. Kuhn, Struktura rewolucji naukowych, Wydawnictwo Aletheia, Warsaw 2009; F. Ashall, Przełomowe odkrycia, Amber, Warsaw 1997.

28 M. Gladwell, Punkt przełomowy: o matych przyczynach wielkich zmian, Społeczny Instytut Wydawniczy, Kraków 2009.

29 P.L. Bernstein, Przeciw Bogom: niezwykte dzieje ryzyka, Kurhaus, Warsaw 2013. 
d) thinking - a network of components of mental processes, through which a man processes content encoded in perceptions, imagery, concepts; this content is encoded by the system of symbols that create the language;

e) language - is the expression of perceptual experience by assigning names to specific spheres of this experience. It enables the performance of cognitive process, using the symbol system that a given language community uses. This system reflects the perceptual and symbolic structures that play a vital role in these communities' lives. Each linguistic community develops its own character (sign) structure, which encodes the meaning of the perceived reality. Thanks to the language, perceptual information can be exchanged.

These cognitive processes overlap each other and are complementary. In fact, none of them can exist independently. It seems that among these processes, attention, registration (perception) and memory are particularly important for detecting and recognising negative effects, including surprises. Within these processes, signals coming from the outside and affecting the sensory organs are converted into sensory experiences. It also seems that these processes include major causes for the limited effectiveness of identifying and recognising "surprises". Being aware of some of the basic mechanisms underlying these elementary cognitive processes may improve the effectiveness of identification and recognition of threats. At the same time, this requires a multidisciplinary approach. The perception of the warning signal can be divided into the following stages:

- sensory reception ${ }^{30}$, where physical energy, such as light waves from the read signs or sound waves, is transformed into nerve cell activity of the cerebral cortex;

- perception in a narrow sense: the inner interpretation of the object is formed, the perceptions of the received impressions arise;

- identification and recognition, where the meaning is given to the perceptions received.

Considering the above, the author proposes the model of perception of a sign, shown below, including, e.g. a warning signal (Figure 2). The perception model illustrated is integrated with other cognitive processes, attention, memory and thinking, so it is proposed to consider it as an integrated model of perception

30 P. Zimbardo, Psychologia i życie, PWN, Warsaw 1999, p. 222-263. 
of a warning signal. In the diagram, we can see two contrary directed streams of processes, i.e. bottom-up processes from the outer environment and top-down processes from the mind.

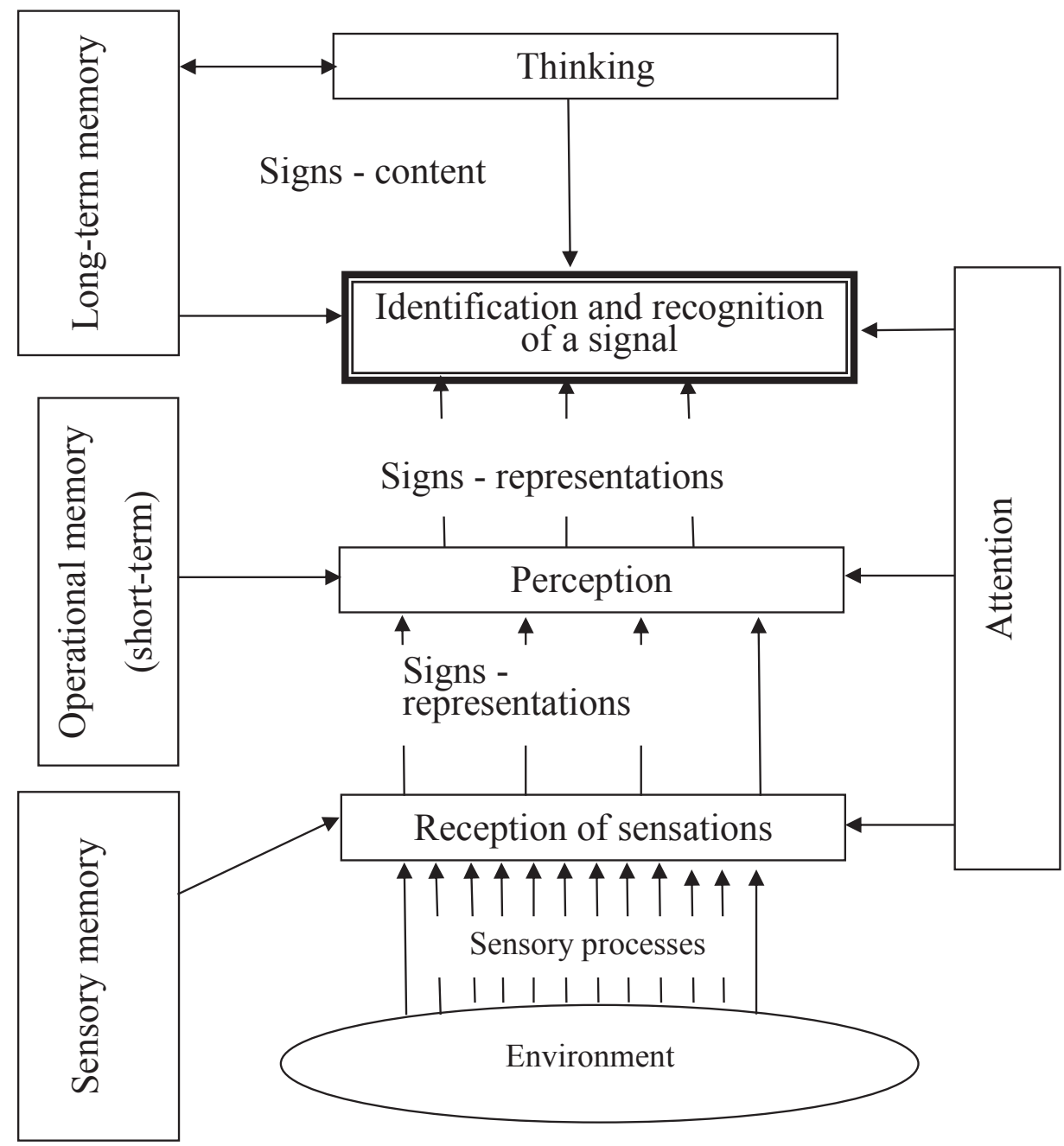

Source: own work.

Fig. 2. Model of integrated warning signal perception

The model of integrated perception of a warning signal in Figure 2 begins with sensory recording of signs representation, which converts the recorded light or sound waves into the nerve impulses in the senses, resulting in sensations (experiences), i.e., reflections of elementary sensory qualities recorded as a result 
of the reception of sensory data. In the specialist literature, sensory data is another stimulus, understood as an environmental factor containing energy and triggering the reaction of the body ${ }^{31}$. Warning signals related to hazards are generally received in visual or ear structures and channels of the observer - biological details of these processes are the material for separate specialist studies, such as the work of Anna Grabowska and Wanda Budohoska ${ }^{32}$ or Peter H. Lindsay and Donald A. Norman ${ }^{33}$. The recorded observations ${ }^{34}$ are confronted with parallel processes of selection and categorisation, which are carried out using memory and thinking in top-down processes, resulting in recognition and identification of the sign content. Such perception is a process of active reception, analysis and interpretation of sensory phenomena. In this process, the incoming sensory information is processed in such a way to adjust it to one's knowledge about the surrounding world.

In general, the identification and recognition of any object, phenomenon or event is nothing else but the interpretation of the perceived signs representations (fig.1), including:

a) assigning the meaning to observations;

b) conscious observation of subject matter:

- giving the perceived representation a name or defining what it is;

- issuing quantitative assessments of the sign content, i.e. how much it is;

- issuing quality assessments of the sign content, i.e. how it is;

- issuing pragmatic judgments, e.g. determining which purpose the object serves and what impact it may cause.

In the case of warning signals, it will mean recognition of a specific reaction, reading its size, comparing it with limit values, risk assessment of exceeding limits taking into account the level of the stress in the environment, and the decision about sending a warning message (notice) to the management.

31 Ibid., p. 269.

32 A. Grabowska, W. Budohoska, Procesy percepcji, PWN, Warsaw 1995.

33 P.H. Lindsay, D.A. Norman, Procesy przetwarzania informacji u człowieka, wprowadzenie do psychologii, PWN, Warsaw 1991.

34 P. Zimbardo, op. cit., pp. 264-307; J.S. Bruner, Poza dostarczone informacje. Studia z psychologii poznania, PWN, Warsaw 1978, pp. 32-226. 
Perception involves integration of a number of components of mental processes, in which the person reflects (creates cognitive representations of) objects of reality currently acting on his receptors and recognises the importance of these objects - decodes incoming information with the help of representations acquainted in his brain. The processes of perception performed in this way are supported by processes of attention, memory and thinking.

\section{Summary}

In the face of growing threats and associated tensions, the sudden explosion of a firecracker during a mass event may trigger panic and mass escape of the crowd an incorrect reading of the signal, resulting in a collective perception in the minds of event members that it is a bomb blast prepared by terrorists. Another example is the underestimation of the real danger associated with the technical condition of a residential building, followed by the fire and death of many residents, with warning signals visible beforehand. It is usual in such situations that information will appear about the possibility of preventing it if the relevant information (signals) had been effectively received.

This indicates the need to undertake analytical and research work in the area of perception of threats. The cognitive factors influencing the perception of warning signals and the associated model of integrated perception of a warning signal could become an important part of the organisation's security systems and should be included in risk monitoring systems. The problem is multidisciplinary, covering the areas of cognitive theory, cognitive psychology, neurology, media and communication theory, and semiotics. 


\section{Bibliography}

Albala-Bertrand J.M., Park M., Disasters and the networked economy, Routledge, Abingdon, New York 2013.

Ashall F., Przełomowe odkrycia, Amber, Warsaw 1997.

Bard A., Soderqvist J., Netokracja: nowa elita wtadzy i życie po kapitalizmie, Wydawnictwa Akademickie i Profesjonalne, Warsaw 2006.

Bernstein P.L., Przeciw Bogom: niezwykte dzieje ryzyka, Kurhaus, Warsaw 2013.

Bobryk J., Akty świadomości i procesy poznawcze, Leopoldinum, Wrocław 1996.

Bruner J.S., Poza dostarczone informacje. Studia z psychologii poznania, PWN, Warsaw 1978.

Chodak J., Teorie rewolucji w naukach społecznych, Wydawnictwo Uniwersytetu Marii Curie-Skłodowskiej, Lublin 2012.

Cybulski W., Graniczne stężenie wybuchowe pytu węglowego jako funkcja stopnia jego rozdrobnienia, Główny Instytut Górnictwa, Katowice 1971.

Ćwik B., Skuteczność rozpoznania sygnałów o zagrożeniach - aspekty teorii znaków [in]: Żylińska J., Przychocka I., Filipowska-Tuthill M., Wspótczesne wyzwania nauk społecznych i ekonomicznych, Uczelnia Techniczno- Handlowa im. Heleny Chodkowskiej w Warszawie, Warsaw 2016.

Ćwik B., Postrzeganie sygnałów ostrzegajacych organizację w sytuacjach niedeterministycznych, WAT, Warsaw 2017.

Dembicki E., Stany graniczne gruntów, teoria $i$ zastosowanie, Zakład Narodowy im. Ossolińskich, Wrocław, 1970.

Dietrich L., Zastosowanie teorii stanów granicznych do wyznaczania obcią̇eń maszyn do robót ziemnych, Instytut Podstawowych Problemów Techniki Polskiej Akademii Nauk, Warsaw 1975.

Gladwell M., Punkt przełomowy: o małych przyczynach wielkich zmian, Społeczny Instytut Wydawniczy, Kraków 2009.

Goban-Klas T., Media $i$ komunikowanie masowe. Teorie $i$ analizy prasy, radia, telewizji $i$ internetu, PWN, Kraków 1999.

Goban-Klas T., Cywilizacja medialna. Geneza, ewolucja, eksplozja, Wydawnictwa Szkolne i Pedagogiczne, Warsaw 2005.

Goffman E., Człowiek $w$ teatrze życia codziennego, Wydawnictwo Aletheia, Warsaw 2008.

Grabowska A., Budohoska W., Procesy percepcji, PWN, Warsaw 1995.

Graniczny M., Katastrofy przyrodnicze, PWN, Warsaw 2007.

Griffin E.A., Podstawy komunikacji społecznej, Gdańskie Wydawnictwo Psychologiczne, Gdańsk 2003.

Hiltunen E., The Future Sign and Its Three Dimension, „Futures”, vol. 40, No 3, 2008.

Innis H.A., Empire and Communications, Dundurn Press, Toronto 2001. 
Izbicki R., Mróz Z., Metody nośności granicznej w mechanice gruntów i skat, Polska Akademia Nauk, Instytut Państwowych Problemów Techniki, Warsaw-Poznań 1975.

Janik P., Koncepcja przekonania w ujęciu semiotyczno-pragmatycznym: Charles S. Peirce, Wydawnictwo WAM, Kraków 2011.

Jędralska K., Zarządzanie niepewnością, Uniwersytet Ekonomiczny w Katowicach, Katowice 2010.

Kalinowski R., Monitorowanie zagrożeń, Wydawnictwo Akademii Podlaskiej w Siedlcach, Siedlce 2003.

Kerckhove D., Powtoka kultury: odkrywanie nowej elektronicznej rzeczywistości, Mikom, Warsaw 2001.

Kittler F.A., Austreibung des Geistes aus den Geisteswissenschaften: Programme den Poststrukturalismus, F. Schöningh, Paderborn 1980.

Kolańczyk A., Czuję, myślę, jestem: świadomość i procesy psychiczne w ujęciu poznawczym, Gdańskie Wydawnictwo Psychologiczne, Gdańsk 1999.

Kozakiewicz K., Określenie granicznych składów gazów zaazotowanych, Centralne Laboratorium Gazownictwa, Warsaw 1967.

Kuhn T., Przewrót kopernikański: astronomia planetarna $w$ dziejach myśli Zachodu, Prószyński i S-ka, Warsaw 2006.

Kuhn T., Struktura rewolucji naukowych, Wydawnictwo Aletheia, Warsaw 2009.

Levinson P., Miękkie ostrze, czyli historia i przyszłość rewolucji informacyjnej, Warszawskie Wydawnictwo Literackie Muza S.A., Warsaw 2006.

Lindsay P. H., Norman D.A.,Procesy przetwarzania informacji u człowieka, wprowadzenie do psychologii, PWN, Warsaw 1991.

Locke J., Rozważania dotyczace rozumu ludzkiego, PWN, Warsaw 1955.

Loska K., Dziedzictwo McLuhana - między nowoczesnościa, a ponowoczesnościa, Rabid, Kraków 2001.

Machowski A. (ed.), Zagadnienia stanów granicznych konstrukcji stalowych, Konferencja naukowa 22-23 kwietnia 2004 r. Kraków, Wydawnictwo Politechniki Krakowskiej, Kraków 2004.

Manovich L., Język nowych mediów, Wydawnictwa Akademickie i Profesjonalne 2006.

Marczak K., Piech K., Cykle koniunkturalne: ujęcie historyczne i przegląd głównych teorii [in:] Koniunktura gospodarcza: od bańki internetowej do kryzysu subprime, Wydawnictwo C. H. Beck, Warsaw 2009.

Maruszewski T., Psychologia poznania. Umyst i świat, Gdańskie Wydaw. Psychologiczne GWP, Gdańsk 2011.

Mcluhan H.M., Zrozumieć media: przedtużenia człowieka, Wydawnictwa NaukowoTechniczne, Warsaw 2004.

Mendera Z., Zagadnienia stanów granicznych konstrukcji stalowych, Politechnika Krakowska, Kraków 1971.

Mersch D., Teorie mediów, Wydawnictwo Sic!, Warsaw 2010. 
Morawski W., Kronika kryzysów gospodarczych, Wydawnictwo TRIO, Warsaw 2003.

Nawrot W., Globalny kryzys finansowy XXI wieku. Przyczyny, przebieg, skutki, prognozy, CeDeWu, Warsaw 2009.

Nęcka E., Orzechowski J., Szymura B., Psychologia poznawcza, PWN, Warsaw 2007.

Probucka D., Etyka wobec sytuacji granicznych, Oficyna Wydawnicza „Impuls”, Kraków 2007.

Przybycień Z. et al., Zbiory graniczne $i$ atraktory $w$ modelach ekonomii matematycznej, Wydawnictwo Akademii Ekonomicznej im. Karola Adamieckiego, Katowice 2006.

Rudziński R., Sytuacje graniczne w ujęciu Karla Jaspersa, Wiedza Powszechna, Warsaw 1978.

Sternberg R.J., Psychologia poznawcza, WSiP, Warsaw 2001.

Strelau J., Psychologia różnic indywidualnych, Wydawnictwo Naukowe" Scholar", Warsaw 2006.

Strelau J., Różnice indywidualne: historia, determinanty, zastosowania, Wydawnictwo Naukowe Scholar: Szkoła Wyższa Psychologii Społecznej, Warsaw 1974, 2015.

Szczepiński W., Stany graniczne i kinematyka ośrodków sypkich, PWN, Warsaw 1974.

Szathmary E., Tajemnice przełomów w ewolucji: od narodzin życia do powstania mowy ludzkiej, PWN, Warsaw 2000.

Tomasello M., Kulturalne źródta ludzkiego poznawania, Państwowy Instytut Wydawniczy, Warsaw 2002.

Urry J., Socjologia mobilności, PWN, Warsaw 2009.

Virilio P., Prędkość i polityka, Wydawnictwo Sic!, Warsaw 2008.

Wallach J., Interpretacja badań laboratoryjnych, MediPage, Warsaw 2011.

Zając A.M., Fenomenologiczne wątki w psychologii poznania: badania Danuty Gierulanki nad przyswajaniem pojęć i rozumieniem tekstu, Wydawnictwo Uniwerytetu Śląskiego, Katowice 2012.

Zimbardo P., Psychologia i życie, PWN, Warsaw 1999.

Żelazny M., Filozofia i psychologia egzystencjalna, Wydawnictwo Naukowe Uniwersytetu Mikołaja Kopernika, Toruń 2011. 